\title{
Pengaruh Normalizing Dengan Variasi Waktu Penahanan Panas (Holding Time) Terhadap Sifat Mekanik Baja ST 46
}

\author{
Sarjito Jokosisworo ${ }^{l)^{*}}$ \\ ${ }^{1)}$ Departemen Teknik Perkapalan, Fakultas Teknik, Universitas Diponegoro \\ Jl. Prof. Soedarto, SH, Kampus Undip Tembalang, Semarang, Indonesia 50275
}

diajukan pada:05/06/18 direvisi pada $: 13 / 07 / 18 \quad$ diterima pada $: 16 / 07 / 18$

\begin{abstract}
Abstrak
Proses perlakuan panas normalizing dilakukan pada baja ST 46 yang merupakan baja tipe low carbon pada pemanasan $880^{\circ} \mathrm{C}$ dengan variasi penahan panas 20 menit dan 40 menit dengan media pendingin udara. Penelitian ini bertujuan membandingkan hasil kekuatan tarik, kekerasan dan mikrografi dari variasi penahan panas dengan menggunakan media pendinginan udara. Hasil penelitian menunjukan bahwa faktor penahanan panas (holding time) berpengaruh dalam nilai tarik, nilai kekerasan dan struktur mikfografi spesimen penelitian. Pada spesimen dengan waktu tahan 20 menit didapatkan nilai tegangan maksimal $334.61 \mathrm{MPa}$, nilai tegangan luluh sebesar 238.09 dan nilai regangan 8.9\%. Sedangkan pada spesimen dengan waktu tahan 40 menit didapatkan nilai tegangan maksimal 328.72 $M P a$, nilai tegangan luluh sebesar 235.61 dan nilai regangan 31.33\%. Pada pengujian kekerasan spesimen dengan waktu tahan 20 menit mempunyai nilai kekerasan 76.11 HRB sedangkan spesimen dengan waktu tahan 40 menit mempunyai nilai kekerasan 70.22 HRB. Dari hasil pengujian tarik dan kekerasan didapatkan bahwa spesimen dengan variasi waktu tahan 20 menit memiliki nilai kekerasan dan nilai tegangan maksimal lebih besar dari variasi penahanan waktu tahan 40 menit. Pada perlakuan panas normalizing dengan variasi 40 menit struktur mikrografinya menunjukkan fasa ferrite lebih dominan, dibandingkan variasi waktu tahan 20 menit.
\end{abstract}

Copyright $\odot$ 2018, KAPAL, 1829-8370 (p), 2301-9069(e)

Kata Kunci : Baja ST 46, Holding Time, Normalizing, Kekuatan Tarik.

\section{PENDAHULAN}

Di masa kini industri baja berkembang cukup pesat, hal ini disebabkan oleh beberapa aspek yang mendukungnya terutama teknologi proses dan teknologi material. Manusia berusaha untuk memperbaiki sifat-sifat fisik dan mekanik dari baja tersebut. Proses perlakuan panas pada baja sangatlah bermanfaat untuk memperbaiki sifatsifat baja. Pada zaman sekarang ini peneliti diharapkan mampu untuk menciptakan produk baja dan material yang mempunyai sifat unggul seperti memiliki nilai kekerasan, sifat keuletan serta ketangguhan yang lebih baik yang nantinya akan dimanfaatkan pada pembuatan benda

\footnotetext{
*) Penulis Korespondensi :
}

Email : sarjitojs@gmail.com tertentu

Proses perlakuan panas memiliki tujuan untuk memperoleh bahan yang memiliki kekuatan keras, lunak, ulet, dan menghilangkan tegangan sisa. Perlakuan panas yang dilakukan sering disebut sebagai cara untuk menaikkan kekerasan bahan, sebenarnya dapat digunakan juga untuk mengubah sifat yang berguna atau dengan kepentingan tertentu untuk keperluan pengguna, seperti: menaikkan sifat mudah dibentuk, mengembalikan elastisitas setelah proses cold work. Bahkan perlakuan panas bukan hanya mengubah sifat material, tapi juga mampu meningkatkan performa material dengan meningkatnya kekuatan atau karakteristik tertentu dari material yang telah diproses laku panas 
Proses normalizing baja merupakan proses pemanasan baja hingga ke fasa austenite sehingga diperoleh struktur mikro austenite, dan didinginkan di udara terbuka hingga temperatur kamar yaitu $27^{\circ} \mathrm{C}$. Sehingga menyebabkan struktur dalam material yang awalnya berubah akibat pembebanan, ataupun digunakan pada temperatur tinggi dapat dikembalikan ke struktur yang normal lewat proses normalizing. Tujuan dari normalizing untuk mengurangi tegangan sisa, memperbaiki sifat mekanik baja serta mengembalikan keuletan baja. [1].

Normalizing adalah proses perlakuan panas dimana proses pemanasan mencapai temperatur, kemudian didinginkan perlahan dengan menggunakan media pendingin udara. Normalizing baja adalah proses pemanasan baja ke fase austenite sehingga diperoleh struktur mikro austenite, selanjutnya didinginkan dengan media pendingin udara normal hingga suhu kamar. Sehingga struktur dalam material yang telah berubah akibat perlakuan mekanik, ataupun karena bekerja pada temperatur tinggi atau rendah dapat dikembalikan ke struktur yang normal lagi melalui proses normalizing.

Awalnya baja dipanaskan diatas suhu kritis $\left(800-950^{\circ} \mathrm{C}\right)$, kemudian setelah mencapai suhu kritisnya baja ditahan (holding) pada suhu tersebut, dan yang terakhir baja didinginkan, pendinginannya sesuai dengan suhu kamar, yaitu didinginkan hingga suhu kurang lebih $27^{\circ} \mathrm{C}$, lama pendinginan inilah yang sangat mempengaruhi sifat mekanik dari baja, semakin cepat pendinginannya maka akan menghasilkan baja dengan sifat mekanik berupa kekuatan dan kekerasan yang lebih tinggi, dan jika pendinginannya lambat maka akan terjadi hal yang sebaliknya.

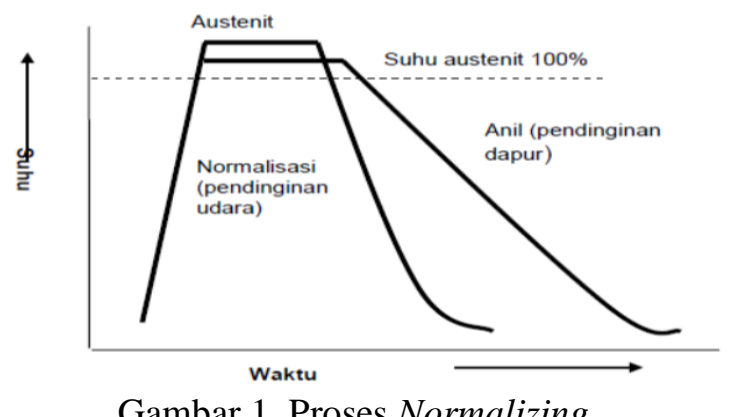

Gambar 1. Proses Normalizing

Pendinginan udara biasanya dilakukan pada proses pemanasan yang membutuhkan pendinginan lambat yaitu normalizing. Untuk keperluan tersebut udara yang mengalir masuk ke dalam ruangan pendingin dibuat dengan kecepatan rendah. Udara sebagai media pendingin akan memberikan kesempatan kepada bahan untuk membentuk kristal dan kemungkinan mengikat unsur lain yang ada di udara. Adapun pendinginan pada udara terbuka akan memberikan oksidasi oksigen terhadap proses pendinginan [2].

Adapun tujuan dari penelitian dengan variasi tanpa perlakuan pendinginan dan perlakuan pendinginan dengan media air laut dan oli adalah untuk mengetahui nilai kekuatan tarik (tensile strength) dari baja ST 46 setelah dilakukan perlakuan panas normalizing pada dua macam variasi waktu penahanan dan melakukan analisa kekuatan tarik (tensile strength) pada baja ST 46. Selain itu untuk mengetahui nilai kekuatan kekerasan dari baja ST 46 setelah dilakukan perlakuan panas normalizing pada dua macam variasi waktu penahanan dan melakukan analisa kekuatan kekerasan pada baja ST 46. Selanjutnya untuk mengetahui bentuk strukur mikro dari baja ST 46 setelah dilakukan perlakuan panas normalizing pada dua macam variasi waktu penahanan.

\section{METODE}

\subsection{Desain Penelitian}

Pengujian dilaksanakan di Laboratorium Bahan Teknik Universitas Gajah Mada Yogyakarta. Metode penelitian yang digunakan adalah metode eksperimental yang dilakukan di laboratorium teknik dengan penekanan pada kekuatan tarik dan kekerasan bahan. Materi penelitian yang dimaksud dalam meliputi datadata yang bersifat primer dan sekunder serta teori dan referensi yang menjadi dasar dalam penelitian ini. Kategori rancangan percobaan yang dipilih adalah spesimen baja ST 46 yang telah mengalami perlakuan panas yaitu spesimen normalizing.

\subsection{Pengujian Tarik}

Pengujian kekuatan tarik merupakan pembebanan pada bahan dengan memberikan gaya yang berlawanan pada bahan dengan arah menjauh dari titik tengah, Pengujian tarik dilakukan untuk mengetahui sifat-sifat mekanis suatu bahan. Pengujian ini paling sering dilakukan karena merupakan dasar pengujian dan studi mengenai kekuatan bahan. Hasil dari penarikan kekuatan tarik terhadap bahan adalah perubahan bentuk (deformasi) bahan, yaitu pergeseran butiran kristal bahan hingga terlepasnya ikatan kristal tersebut karena gaya maksimum [3].

Proses terjadinya deformasi pada bahan sampai putus, dapat diketahui melalui tahapan pengujian tarik. Hasil pengukuran dari pengujian tarik adalah suatu kurva yang memberikan 
hubungan antara gaya yang dipergunakan dan perpanjangan yang dialami oleh spesimen

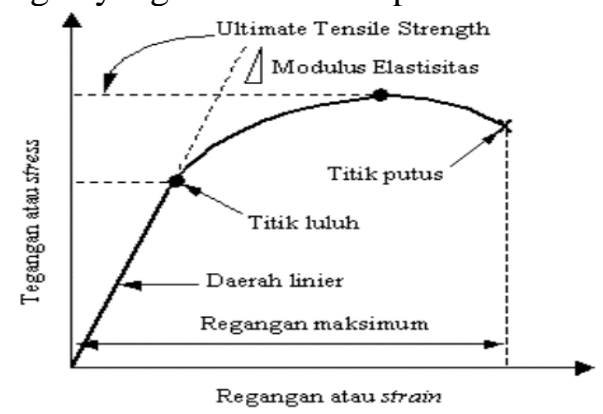

Gambar 3. Kurva tegangan regangan Baja

Sifat mekanik pertama yang dapat diketahui dari kurva pengujian tarik yang dihasilkan adalah kekuatan tarik maksimum yang diberi simbol $u$. simbol u didapat dari kata ultimate yang berarti puncak. Jadi besarnya kekuatan tarik ditentukan oleh tegangan maksimum yang diperolehdari kurva tarik.

Pada kurva tarik baja karbon rendah batas ini mudah terlihat, tetapi pada bahan lain batas ini sukar sekali untuk diamati oleh karena daerah linier dan tidak linier bersambung secara berkelanjutan. Oleh karena itu untuk menentukan titik luluh diambil dengan metode off set yaitu suatu metode yang menyatakan bahwa titik luluh adalah suatu titik pada kurva yang menyatakan dicapainya regangan plastis sebesar $0,2 \%$.

\subsection{Pengujian Kekerasan}

Pengujian kekerasan bahan merupakan kemampuan bahan terhadap pembebanan dalam perubahan yang tetap, ketika gaya tertentu diberikan pada suatu benda uji. Harga kekerasan bahan tersebut dapat dianalisis dari besarnya beban yang diberikan terhadap luasan bidang yang menerima pembebanan [3].

Indentor dapat berupa bola baja atau kerucut intan dengan ujung yang membulat (brale). Diameter bola baja umumnya $1 / 16$ inchi, tetapi terdapat juga indentor dengan diameter lebih besar, yaitu 1/8,1/4, atau 1/2 inchi untuk bahanbahan yang lunak. Pengujian dilakukan dengan terlebih dahulu memberikan beban minor $10 \mathrm{~kg}$, dan kemudian beban mayor diaplikasikan. Beban mayor biasanya 60 atau $100 \mathrm{~kg}$ untuk indentor bola baja dan $150 \mathrm{~kg}$ untuk indentor brale. Mesikpun demikian, dapat digunakan beban dan indentor sesuai kondisi pengujian. Karena pada pengujian rockwell, angka kekerasan yang ditunjukkan merupakan kombinasi antara beban dan indentor yang dipakai, maka perlu diberikan awalan huruf pada angka kekerasan yang menunjukkan kombinasi beban dan penumbuk tertentu untuk skala beban yang digunakan.

\subsection{Pengujian Mikrografi}

Pengujian Mikrografi bertujuan untuk memperoleh gambar yang menunjukan struktur mikro sebuah bahan. Melalui Proses ini kita dapat mengetahui struktur dari suatu bahan dengan memperjelas batas-batas butir bahan sehingga dapat langsung dilihat dengan menggunakan mikroskop dan diambil gambarnya. Pengujian mikrografi dimaksudkan untuk melihat perubahan struktur pada bahan. [4]

\subsection{Spesimen Material Uji}

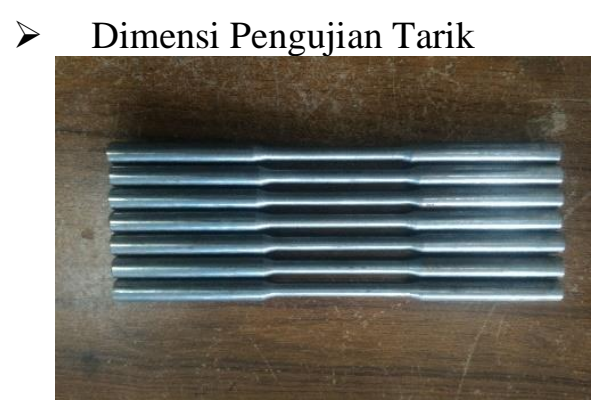

Gambar 4. Bentuk Spesimen Uji tarik

\section{$>\quad$ Dimensi Pengujian Kekerasan}

Dimensi spesimen pengujian kekerasan menggunakan tabung silindris dengan tebal 10 $\mathrm{mm}$.

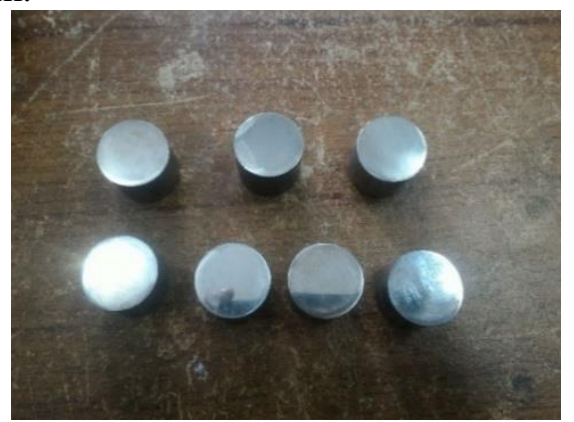

Gambar 5. Bentuk Spesimen Uji Kekerasan

\section{HASIL DAN PEMBAHASAN}

\subsection{Pengujian Komposisi}

Uji komposisi bertujuan untuk mengetahui presentase unsur kimia yang terkandung di dalam spesimen sebelum dilakukan perlakuan panas normalizing. Unsur-unsur yang yang terkandung di dalam baja sangat mempengaruhi sifat mekanis dari baja tersebut. Dan juga jenis-jenis baja umumnya ditentukan berdasarkan kandungan karbon di dalam material baja tersebut. 
Tabel 1. Komposisi Kimia Baja ST 46

\begin{tabular}{ccc}
\hline \multicolumn{2}{c}{ UNSUR } & $(\boldsymbol{\%})$ \\
\hline $\mathrm{C}$ & (Carbon) & 0,1675 \\
$\mathrm{Si}$ & (Silikon) & 0,2551 \\
$\mathrm{~S}$ & (Belerang) & 0,0047 \\
$\mathrm{P}$ & (Fosfor) & 0,0159 \\
$\mathrm{Mn}$ & (Mangan) & 0,5275 \\
$\mathrm{Ni} \quad$ (Nikel) & 0,0175 \\
$\mathrm{Cr} \quad$ (Krom) & 0,3546 \\
$\mathrm{Mo} \quad$ (Molibdenum) & 0,0241 \\
$\mathrm{~W} \quad$ (Wolfram) & 0,0000 \\
$\mathrm{Ti}$ & (Talium) & 0,0029 \\
$\mathrm{Sn}$ & (Timah) & 0,013 \\
$\mathrm{Al} \quad$ & (Alumunium) & 0,0103 \\
$\mathrm{Nb}$ & (Niobium) & 0,0000 \\
$\mathrm{~V} \quad$ (Vanadium) & 0,0076 \\
$\mathrm{Co}$ & (Kobal) & 0,0046 \\
$\mathrm{~Pb}$ & (Timbal) & 0,0000 \\
$\mathrm{Ca}$ & (Kalsium) & 0,0014 \\
$\mathrm{Zn}$ & (Seng) & 0,0000 \\
$\mathrm{Fe}$ & (Besi) & 98,58 \\
\hline
\end{tabular}

Berdasarkan hasil pengujian yang telah dilakukan, spesimen baja yang nantinya akan dilakukan proses normalizing merupakan baja tiper karbon rendah. Baja karbon rendah mengandung karbon kurang dari 0,3\%, sedangkan hasil pengujian dapat diketahui spesimen baja yang nantinya akan dilakukan proses normalizing memiliki kadar karbon sebesar $0,1675 \%$. Hal ini sesuai dengan karakter baja ST 46 yang merupakan baja tipe karbon rendah

\subsection{Pengujian Tarik}

Pengujian tarik ini dilakukan sebanyak tujuh kali menggunakan baja ST 46 sebanyak tujuh spesimen dengan dimensi dan beban yang sama dengan pembagian. Satu spesimen yang belum dilakukan perlakuan panas ( Raw Material), tiga spesimen yang mengalami perlakuan panas dengan holding time selama 20 menit dan tiga spesimen yang mengalami perlakuan panas dengan holding time selama 40 menit.
Pengujian ini dilakukan secara komputerisasi sehingga kurva tegangan regangan bisa langsung diketahui. Dimana untuk nilai tegangan adalah besarnya beban dibagi dengan luas penampang awal, sedangkan nilai regangan adalah pertambahan panjang spesimen dibagi dengan panjang mula-mula spesimen

Tabel 2. Hasil Pengujian Tarik

\begin{tabular}{|c|c|c|c|}
\hline $\begin{array}{c}\text { Perlakuan } \\
\text { Panas }\end{array}$ & $\begin{array}{c}\text { Teg. } \\
\text { Luluh } \\
\left(\sigma_{y}\right) \\
(\text { Mpa })\end{array}$ & $\begin{array}{c}\text { Teg. Max } \\
\left(\sigma_{U}\right) \\
(\mathbf{M P a})\end{array}$ & $\begin{array}{c}\text { Regangan } \\
(\varepsilon) \\
(\%)\end{array}$ \\
\hline $\begin{array}{c}\text { Raw } \\
\text { Material }\end{array}$ & 549.98 & 559.92 & 8.9 \\
\hline \multirow{3}{*}{$\begin{array}{c}\text { Holding } \\
\text { time } 20 \\
\text { menit }\end{array}$} & 248.30 & 338.31 & 31.2 \\
\hline & 238.09 & 334.61 & 34.3 \\
\hline & 238.33 & 336.85 & 30.5 \\
\hline \multirow{3}{*}{$\begin{array}{c}\text { Holding } \\
\text { time } 40 \\
\text { menit }\end{array}$} & 245.34 & 328.14 & 32.7 \\
\hline & 227.50 & 328.60 & 30.8 \\
\hline & 234.00 & 329.44 & 30.5 \\
\hline
\end{tabular}

Berdasarkan Tabel 2 dapat diketahui bahwa baja ST 46 dengan perlakuan panas normalizing holding time 20 menit memiliki kekuatan tarik 336.53 Mpa dan kekuatan luluh sebesar 241.75 Mpa. Sedangkan pada tabel 4.6 menunjukan bahwa baja ST 46 dengan perlakuan panas normalizing holding time 40 menit memiliki kekuatan tarik $328.72 \mathrm{Mpa}$ dan kekuatan luluh sebesar 235.61 Mpa. Hal ini menunjukan bahwa baja ST 46 perlakuan panas normalizing holding time 20 menit mempunyai kekuatan ulet (ductile) yang lebih baik dibandingkan dengan baja ST 46 perlakuan panas normalizing holding time 40 menit

\subsection{Pengujian Kekerasan}

Metode pengujian kekerasan yang digunakan pada tugas akhir ini adalah metode rockwell tipe B dimana beban yang diberikan sebesar $100 \mathrm{~kg}$ dengan indenter berbentuk kerucut intan. Pengujian dilakukan pada tiga spesimen yang telah mengalami normalizing dengan waktu penahanan 20 menit, tiga spesimen yang telah mengalami normalizing dengan waktu penahan 40 menit dan juga satu spesimen yang tidak dilakukan perlakuan panas. Pada tiap spesimen dilakukan indentasi sebanyak tiga kali. Pada 
pengujian kekerasan, permukaan spesimen harus dihaluskan dengan cara diamplas.

Tabel 3 Hasil Pengujian Kekerasan

\begin{tabular}{|c|c|c|c|c|c|c|}
\hline No & Spesimen & $\begin{array}{l}\text { Posisi } \\
\text { titik uji }\end{array}$ & $\mathrm{Uji} 1$ & $\mathrm{Uji} 2$ & $\mathrm{Uji} 3$ & $\begin{array}{c}\text { Kekerasan } \\
\text { (HRB) }\end{array}$ \\
\hline 1 & Raw Material & Acak & 92.0 & 89.0 & 92 & 91 \\
\hline 2 & Holding time 20 menit & Acak & 75.0 & 75.0 & 75.0 & 75 \\
\hline 3 & Holding time 20 menit & Acak & 77.0 & 77.0 & 79.0 & 77.67 \\
\hline 4 & Holding time 20 menit & Acak & 74.0 & 76.0 & 77.0 & 75.67 \\
\hline 5 & Holding time 40 menit & Acak & 70.0 & 72.0 & 69.0 & 70.33 \\
\hline 6 & Holding time 40 menit & Acak & 70.0 & 70.0 & 69.0 & 69.67 \\
\hline
\end{tabular}

\section{Nilai Kekerasan Baja ST 46}

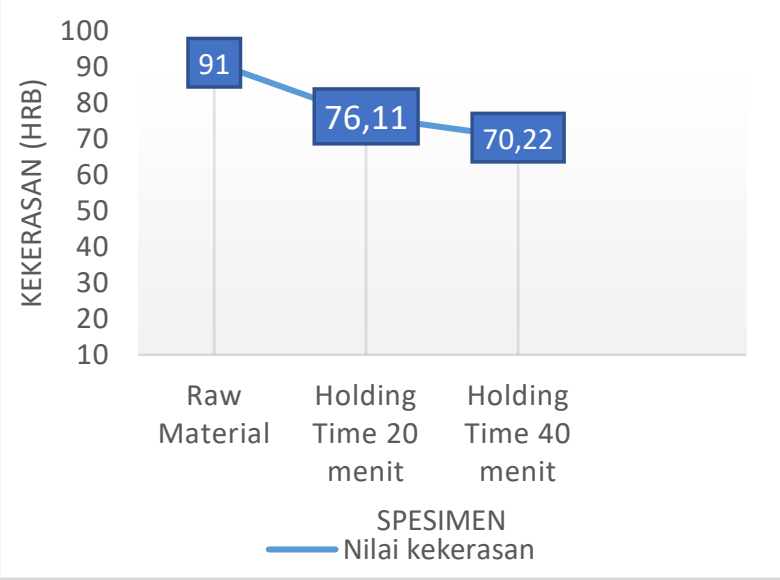

Gambar 6. Diagram Nilai rata-rata Kekerasan

Berdasarkan gambar 6 dapat diketahui bahwa nilai kekerasan baja ST 46 tanpa perlakuan panas adalah $91 \mathrm{HRB}$, nilai dari kekerasan baja ST 46 dengan variasi penahanan panas 20 menit memiliki rata-rata sebesar $76.11 \mathrm{HRB}$, dan nilai dari kekerasan baja ST 46 dengan variasi penahanan panas 40 menit memiliki rata-rata sebesar 70.22 HRB.

Dapat disimpulkan bahwa semakin lama spesimen mengalami perlakuan panas normalizing, maka semakin berkurang nilai kekerasannya. Perbedaan nilai tersebut diakibatkan oleh pengaruh lama waktu spesimen mengalami perlakuan panas sehingga menyebabkan nilai kekerasan menjadi turun. Selain itu, lama waktu perlakuan panas juga menyebabkan struktur mikro spesimen menjadi ikut berubah.

\subsection{Hasil Pengujian Mikrografi}

Untuk proses pengerjaan pengujian mikrografi tahapan yang harus dilakukan sebelum hasil dapat dilihat struktur mikro dan makronya terlebih dahulu material di grinding dengan mesin grinding putar. Sebagai medium grinding dipakai kertas amplas dengan nomor 100, 200, 400, 600, 800,1500 dan 2000. Ketika sampel mengalami grinding diatas kertas amplas, harus dialiri air bersih secara berkelanjutan dengan tujuan untuk menghindari timbulnya panas di pemakaian sampel yang kontak langsung dengan kertas amplas. setelah proses pengamplasan hingga halus maka material harus di autosol hingga material yang sudah di amplas mengkilap. Lalu proses dilanjutkan dengan pengetsaan

Pengujian mikrografi pada penelitian ini dilakukan pada tiga jenis spesimen, yaitu : Baja ST 46 tanpa perlakuan panas, baja ST 46 perlakuan panas dengan variasi penahanan panas 20 menit, dan baja baja ST 46 perlakuan panas dengan variasi penahanan panas 40 menit $\mathrm{Hal}$ ini dilakukan untuk mengetahui dan membandingkan perubahan struktur mikro baja ST 46 karena mendapat proses perlakuan panas (heat treatment). Pengujian mikrografi ini dilakukan dengan dua kali pembesaran 100 dan 200 pada tiap-tiap spesimen

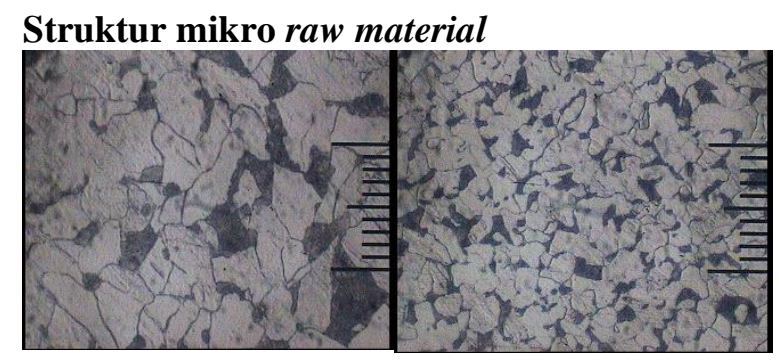

(1)

(2)

Gambar 7. (1) Perbesaran 100 (2) Perbesaran 200

Struktur mikro variasi penahanan panas 20 menit.

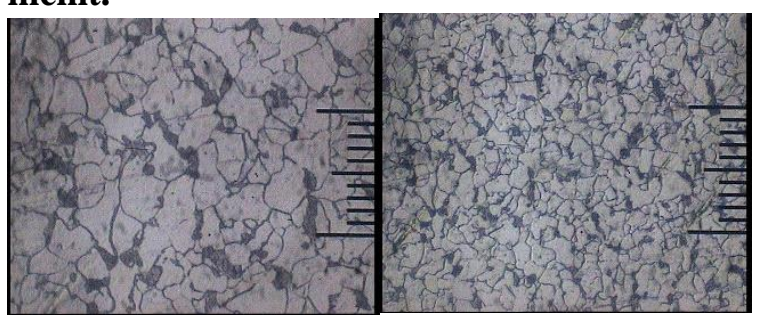

(1)

(2)

Gambar 8. (1) Perbesaran 100 (2) Perbesaran 200 
Struktur mikro variasi penahanan panas 40 menit.

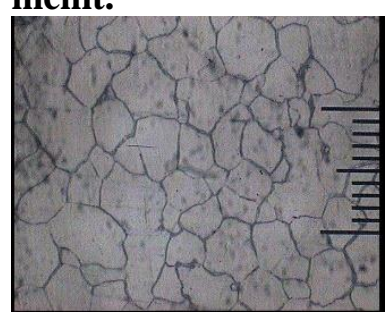

(1)

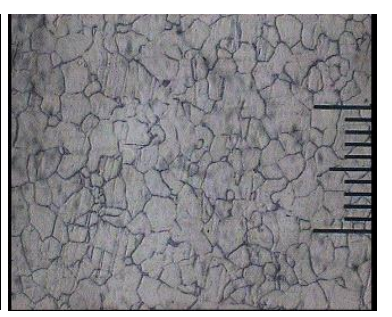

(2)
Gambar 9. (1) Perbesaran 100 (2) Perbesaran 200

Berdasarkan pengujian mikrografi baja ST 46 yang telah dilakukan proses perlakuan panas (heat treatment) akan mengubah struktur mikro pada material. Perlakuan panas normalizing dengan holding time 20 menit memiliki kekerasan yang lebih tinggi, diikuti dengan baja ST 46 perlakuan panas normalizing dengan holding time 40 menit, hal tersebut dikarenakan baja ST 46 perlakuan panas normalizing dengan holding time 20 menit memiliki fasa sementite yang lebih dominan dibandingkan dengan baja ST 46 perlakuan panas normalizing dengan holding time 40 menit.

Perlakuan panas normalizing dengan holding time 40 menit memiliki nilai keuletan (ductile) yang lebih tinggi, diikuti dengan baja dengan holding time 20 menit hal tersebut dikarenakan baja ST 46 normalizing dengan holding time 40 menit memiliki fasa ferrite yang lebih dominan dibandingkan dengan baja ST 46 perlakuan panas normalizing dengan holding time 20 menit.

\section{KESIMPULAN}

Berdasarkan pengujian tarik yang telah dilakukan, baja ST 46 dengan perlakuan panas normalizing variasi penahanan panas 20 menit memiliki nilai tegangan luluh sebesar 241.57 Mpa, dan memiliki nilai tegangan maksimum sebesar 336.53 Mpa. Sedangkan baja ST 46 dengan perlakuan panas normalizing variasi penahanan panas 40 menit memiliki nilai tegangan luluh sebesar 235.61 Mpa, dan memiliki nilai tegangan maksimum sebesar 328.72 Mpa.Sehingga semakin cepat proses penahanan panas pada spesimen semakin tinggi nilai tegangan maksimum dan tegangan luluh spesimen tersebut.

Berdasarkan pengujian kekerasan yang telah dilakukan, baja ST 46 dengan perlakuan panas normalizing variasi penahanan panas 20 menit memiliki nlai kekerasan sebesar 76.11 HRB, sedangkan baja ST 46 dengan perlakuan panas normalizing variasi penahanan panas 40 menit memiliki nilai kekerasan sebesar 70.22 HRB. Sehingga baja ST 46 dengan perlakuan panas normalizing variasi penahanan panas 20 menit cenderung lebih keras dibandingkan dengan baja St 46 dengan perlakuan panas normalizing variasi penahanan panas 40 menit.

Berdasarkan pengujian mikrografi yang telah dilakukan, perlakuan panas normalizing dengan variasi penahan panas menghasilkan perubahan struktur yang mengakibatkan perbedaan perbedaan nilai pada pengujian tarik maupun kekerasan.

\section{DAFTAR PUSTAKA}

[1] Karokaro, Muchtar. 2001. Pengaruh normalizing ulang terhadap sifat kelelahan baja DIN 42MnV7, Jurusan Teknik Mesin , Fakultas Teknik Industri, Institut Teknologi Sepuluh November, Surabaya.

[2] Murtiono, Arief. 2012, Pengaruh Quenching dan Tempering terhadap kekerasan dan kekuatan tarik serta struktur mikro baja karbon sedang untuk mata pisau permanen sawit, Departemen Teknik Mesin, Universitas Sumatera Utara, Medan.

[3] Pribadi, Bangun. Suprapto. Dan Dwi Priyantoro, 2009. Pengaruh normalisai terhadap sifat kekerasan dan struktur mikro baja tahan karat setelah proses pengerolan, Badan Teknologi Nuklir, Yogyakarta.

[4] Cahyono, Azis. 2015. Heat Treatment (Perlakuan Panas) Dengan cara Normalizing, Jurusan Teknik Mesin , Universitas Negeri Semarang, Semarang 